\title{
Vitamin D improves immune function in immunosuppressant mice induced by glucocorticoid
}

\author{
ZONGYE WANG $^{1}$, YING WANG $^{1}$, BINGXIN XU $^{2}$, JUNLI LIU $^{2}$, YE REN $^{1}$, ZHUOJIE DAI $^{1}$, \\ DI CUI ${ }^{1}$, XIAOMING SU${ }^{1}$, SHAOYAN SI ${ }^{2}$ and SHU JUN SONG ${ }^{2}$ \\ ${ }^{1}$ Department of Therapeutic Radiology and Oncology; ${ }^{2}$ Center for Special Medicine and Experimental Research, \\ The 306th Hospital of PLA, Chao Yang, Beijing 100101, P.R. China
}

Received September 29, 2016; Accepted November 21, 2016

DOI: $10.3892 /$ br.2016.817

\begin{abstract}
Vitamin D is an essential fat-soluble vitamin with multiple functions. Vitamin D receptor has been shown to be expressed in several types of immune cells suggesting vitamin D may have immune regulatory roles. Vitamin D insufficiency has been suggested to increase the risk of autoimmune diseases. However, little is known regarding its immunomodulatory effects in the condition of immune suppression. The aim of the present study was to investigate the regulatory effects of vitamin D on immune function in immunosuppressant mice. An immunosuppressant mouse model was induced by intraperitoneal injection with glucocorticiod for 3 days. Immunosuppressant mice were intragastrically administered with 1,25-dihydroxy-vitamin D3 $\left[1,25(\mathrm{OH})_{2} \mathrm{D}_{3} ; 0,4,6\right.$ or $10 \mathrm{IU} / \mathrm{g}$ body weight] for 7 days. On day 8 , the mice were decapitated. The body weight and the weights of thymus and spleen were measured. Thymus and spleen indexes were calculated. The ratio of $\mathrm{CD}^{+} / \mathrm{CD}^{+} \mathrm{T}$ lymphocytes in the peripheral blood, proliferation and interleukin-2 (IL-2) production of spleen $\mathrm{T}$ lymphocytes was detected. Compared with the mice in the control group, the body weight, thymus and spleen indexes, the ratios of $\mathrm{CD}^{+} / \mathrm{CD}^{+}$in peripheral blood and IL-2 production and proliferation of spleen $\mathrm{T}$ lymphocytes were decreased in immunosuppressant mice induced by glucocorticiod. However, in vitamin D-treated mice, the thymus indexes, the ratios of $\mathrm{CD}^{+} / \mathrm{CD}^{+}$, secretion of IL-2 and the proliferation index of spleen $\mathrm{T}$ lymphocytes were significantly increased $(\mathrm{P}<0.05)$.
\end{abstract}

Correspondence to: Dr Shu Jun Song or Dr Shaoyan Si, Center for Special Medicine and Experimental Research, The 306th Hospital of PLA, 9 An Xiang Bei Lu, ChaoYang, Beijing 100101, P.R. China E-mail: shuj80@126.com

E-mail: sishy306@126.com

Abbreviations: $\mathrm{OH}$, hydroxide; $1,25(\mathrm{OH})_{2} \mathrm{D}_{3}$, 1,25-dihydroxy vitamin D3; Con A, concanavalin A; MTT, 3-(4,5-dimethyl thiazol-2-yl)-2,5-diphenyl-tetrazolium bromide; IL-2, interleukin-2; ELISA, enzyme-linked immunosorbent assay; DEX, dexamethasone; FCS, fetal calf serum; OD, optical density

Key words: vitamin D, immunity, T lymphocytes, interleukin-2
Among the three doses of $1,25(\mathrm{OH})_{2} \mathrm{D}_{3}, 6 \mathrm{IU} / \mathrm{g}$ was most effective in improving the immune function. These results indicate that vitamin D supplementation can improve immune recovery in immunosuppressant mice by stimulating T-cell proliferation and elevating IL-2 production.

\section{Introduction}

Vitamin D is an essential fat-soluble vitamin with multiple functions. The main source of vitamin D is transformed from 7-dehydrocholesterol after exploration with ultraviolet irradiation and sequential hydroxylation into $25(\mathrm{OH}) \mathrm{D}$ and an active hormone, 1,25-dihydroxy-vitamin $\mathrm{D} 3\left[1,25(\mathrm{OH})_{2} \mathrm{D}_{3}\right]$, by hydroxylases in the kidney and liver. It can also be absorbed from dietary intake or oral supplements. It has been shown that vitamin D receptor (VDR) is highly expressed in the intestine, kidney, thyroid and bone (1). Previous findings showed that several types of immune cells such as T lymphocytes, monocytes, macrophages, and dendritic cells express VDR as well. The active form of vitamin $\mathrm{D}$ exerts its effects on these tissues by binding to VDR. In addition, some studies present that macrophages, dendritic cells and lymphocytes also express vitamin D activating enzyme, 1- $\alpha$-hydroxylase (CYP27B1) (2,3). Therefore, except for the classical physiological function of regulation of calcium and bone metabolism, vitamin D may also have immunomodulatory effects.

Epidemiologic evidence indicates that vitamin D deficiency is related to autoimmune diseases including multiple sclerosis, type 1 diabetes, systemic lupus erythematosus (SLE) and inflammatory bowel disease (4). Studies have found that the levels of serum $25(\mathrm{OH}) \mathrm{D}$ and $1,25(\mathrm{OH})_{2} \mathrm{D}_{3}$ are significantly lower in patients with multiple sclerosis than those in healthy controls $(5,6)$. Additionally, the effect of vitamin D on type 1 diabetes mellitus is closely correlated with the serum concentration of 25(OH)D. An epidemiological investigation in Britain by Staples et al proves that the prevalence of type 1 diabetes is positively associated with the increase of residential latitude, and inversely associated with ultraviolet radiation, which is consistent with a previous report for multiple sclerosis in Australia (7). Additionally, the percentage of SLE has a close relationship with the serum concentration of $25(\mathrm{OH}) \mathrm{D}$. In the study of Ruiz-Irastorza et al, the percentage of vitamin D deficiency in patients with SLE was higher than that in the 
healthy population, and approximately $70 \%$ of SLE patients had a serum concentration of $25(\mathrm{OH}) \mathrm{D}<30 \mathrm{ng} / \mathrm{ml}(8)$.

In addition to epidemiological data, animal experiments have also presented relationships between vitamin D and autoimmune diseases. In the study of Ye et al, the percentage of $\mathrm{CD}^{+}$and $\mathrm{CD}^{+} \mathrm{T}$ lymphocytes in guinea pigs with experimental allergic encephalomyelitis was decreased and the $\mathrm{CD}^{+} / \mathrm{CD}^{+}$ratio was increased. However, when guinea pigs were supplemented with $1,25(\mathrm{OH})_{2} \mathrm{D}_{3}$, the percentage of $\mathrm{CD}^{+}$and $\mathrm{CD}^{+} \mathrm{T}$ lymphocyte were significantly elevated and simultaneously, $\mathrm{CD} 4^{+} / \mathrm{CD}^{+}$was reduced (9). Another study showed that the immunological rejection of corneal allograft was inhibited by $1,25(\mathrm{OH})_{2} \mathrm{D}_{3}(10)$. Furthermore, $1,25(\mathrm{OH})_{2} \mathrm{D}_{3}$ also inhibited the expression of inflammatory related cytokines, such as interferon- $\gamma$, interleukin-2 (IL-2) and interleukin-17A (10).

However, little is known about the immunomodulatory effects of vitamin D in the condition of immune suppression. Vitamin D deficiency increases the susceptibility and vulnerability to tuberculosis. The immune response of patients with type 2 diabetes and spinal tuberculosis who receive long-term drug therapy can be improved by supplementation with $1,25(\mathrm{OH})_{2} \mathrm{D}_{3}(11,12)$. Those studies suggested that vitamin D may enhance the immune function under immunocompromised condition. The aim of the present study was to investigate the effects of vitamin D on immune function in immunosuppressant mice induced by glucocorticoid.

\section{Materials and methods}

Reagents. Concanavalin A (Con A), 1,25(OH $)_{2} \mathrm{D}_{3}$ and 3-(4,5-dimethylthiazol-2-yl)-2,5-diphenyl-tetrazolium bromide (MTT) were purchased from Sigma (St. Louis, MO, USA). A mouse enzyme-linked immunosorbent assay (ELISA) kit for IL-2 was purchased from R\&D Systems, Inc., (Minneapolis, MN, USA). Fluorescence-labeled anti-mouse antibody was purchased from eBioscience, Inc. (San Diego, CA, USA).

Animal studies. A total of 40 ICR male mice (6-8 weeks old) were purchased from the Animal Center of the Medical Laboratory in Peking University Health Science Center. Mice were randomly divided into five groups (8 in each group) including the control group (C group), immunosuppression model group (M group) and three different doses of $1,25(\mathrm{OH})_{2} \mathrm{D}_{3}$ supplemented groups. All the mice except those in the $\mathrm{C}$ group were injected intraperitoneally with dexamethasone (DEX, $25 \mathrm{mg} / \mathrm{kg}$ ) for three days to establish the immunosuppressant mouse model. Mice in the $\mathrm{C}$ group were injected with the same volume of normal saline. From the first day of DEX injection, $1,25(\mathrm{OH})_{2} \mathrm{D}_{3}$ at three different doses of $4 \mathrm{IU} / \mathrm{g}$ (+4D group), $6 \mathrm{IU} / \mathrm{g}$ (+6D group) or $10 \mathrm{IU} / \mathrm{g}$ (+10D group) body weight was given for 7 days by intragastric administration to mice in vitamin D-treated groups. Mice in the $\mathrm{C}$ and $\mathrm{M}$ groups received the same volume of physiological saline via intragastric administration.

All the mice were weighed and sacrificed by cervical dislocation at day 8 . Spleens and thymuses were collected and weighed. Indexes for thymus and spleen were calculated according to the formulae: Spleen index $(\mathrm{mg} / \mathrm{g})=$ weight of spleen (mg)/body weight $(\mathrm{g})$ and thymus index = weight of thymuses $(\mathrm{mg}) /$ body weight $(\mathrm{g})$. Animal experiments performed in the study were approved by the Ethics Committee (ref no. LUNSHEN 2014012) of the 306th Hospital of PLA (Beijing, China).

Proliferation assay of splenocytes. Cell proliferation was assessed by MTT assay. The splenocyte suspension was obtained by grinding the spleen tissue in RPMI-1640 and passing tissue through a fine-mesh cell strainer. Erythrocytes were removed by hemolytic solution. Cells were washed, centrifuged and suspended in RPMI-1640 with 10\% fetal calf serum (FCS). Cells were counted, and resuspended in culture medium at a concentration of $1 \times 10^{7}$ cells $/ \mathrm{ml}$. Cells $(100 \mu \mathrm{l} /$ well) were seeded in 96-well plates. Culture medium (100 $\mu \mathrm{l} / \mathrm{well})$ containing Con A $(10 \mu \mathrm{g} / \mathrm{ml})$ or without Con A (as control) was added to each well and cultured for $48 \mathrm{~h}$. Cell proliferation was detected by MTT assay. MTT reagent $(20 \mu 1,5 \mathrm{mg} / \mathrm{ml})$ was added to each well and cultured for an additional $4 \mathrm{~h}$. Culture medium was discarded and $100 \mu \mathrm{l}$ dmethyl sulfoxide was added to each well. Optical density (OD) value was read at $570 \mathrm{~nm}$ using a spectrophotometer (Bio-Rad Laboratories, Hercules, CA, USA). Stimulated proliferation index was calculated according to the formula: Proliferation index $=\mathrm{OD}_{\mathrm{ConA}} / \mathrm{OD}_{\text {control }}$.

Quantification for IL-2 production. The concentration of IL-2 in cultures of splenocytes was determined using a mouse ELISA kit. Cells from spleen were prepared as described in the proliferation assay. Cells $\left(10^{7} / \mathrm{ml} ; 350 \mu \mathrm{l} /\right.$ well $)$ were plated on 24-well plates and $350 \mu \mathrm{l} /$ well Con A $(10 \mu \mathrm{g} / \mathrm{ml})$ was added to each well and cultured for $48 \mathrm{~h}$. The cell culture medium was collected. The concentration of IL-2 in cell culture medium was detected by ELISA following the manufacturer's instructions.

Flow cytometric analysis of cell markers of CD4 and CD8. To determine the ratio of $\mathrm{CD}^{+}$and $\mathrm{CD} 8^{+} \mathrm{T}$ lymphocytes $\left(\mathrm{CD}^{+} / \mathrm{CD}^{+}\right)$in peripheral blood, the anticoagulated blood was collected from all the mice and treated with haemolysin. Cells were washed and cell suspension was prepared for immunofluorescent staining. Fluorescein-labeled rat anti-mouse monoclonal antibodies (1:200 diluted anti-CD4 FITC, cat. no. 11-0041; and 1:200 diluted anti-CD8 PE, cat. no. 12-0081) were added to the cells and incubated for $30 \mathrm{~min}$ in dark. The cells were washed and analyzed by FACSCalibur and Cell Quest software (BD Biosciences, Franklin Lakes, NJ, USA).

Statistical analysis. Statistical analysis was performed using Statistical Product and Service Solutions (SPSS, Armonk, NY, USA) software version 16.0. Data were expressed as mean \pm standard deviation (mean $\pm \mathrm{SD}$ ). One-way ANOVA analysis was carried out to compare means variability among all the groups. $\mathrm{P}<0.05$ was considered to indicate a statistically significant difference.

\section{Results}

$1,25(\mathrm{OH})_{2} \mathrm{D}_{3}$ improves immune organ recovery. As shown in Table I, the thymus and spleen indexes in mice in the $\mathrm{M}$ group were significantly lower than those in mice in the 
Table I. The effect of $1,25(\mathrm{OH})_{2} \mathrm{D}_{3}$ on thymus index and spleen indexes (mean $\pm \mathrm{SD}$ ).

\begin{tabular}{lcrcr}
\hline Groups & Thymus $(\mathrm{mg})$ & Spleen $(\mathrm{mg})$ & Thymus index $(\mathrm{mg} / \mathrm{g})$ & Spleen index $(\mathrm{mg} / \mathrm{g})$ \\
\hline $\mathrm{C}$ & $73.38 \pm 11.53$ & $109.09 \pm 22.42$ & $2.83 \pm 0.42$ & $4.20 \pm 0.73$ \\
M & $32.43 \pm 8.07^{\mathrm{a}}$ & $79.08 \pm 17.09$ & $1.23 \pm 0.30^{\mathrm{a}}$ & $3.01 \pm 0.62^{\mathrm{a}}$ \\
+4D & $41.79 \pm 6.27^{\mathrm{a}}$ & $78.48 \pm 17.75$ & $1.77 \pm 0.21^{\mathrm{a}, \mathrm{b}}$ & $3.3 \pm 0.72$ \\
+6D & $66.99 \pm 15.36^{\mathrm{b}}$ & $78.06 \pm 13.41$ & $2.58 \pm 0.62^{\mathrm{b}}$ & $2.99 \pm 0.46^{\mathrm{a}}$ \\
+10D & $55.75 \pm 15.95^{\mathrm{b}}$ & $76.99 \pm 10.3^{\mathrm{a}}$ & $2.11 \pm 0.53^{\mathrm{a}, \mathrm{b}}$ & $2.93 \pm 0.37^{\mathrm{a}}$ \\
\hline
\end{tabular}

${ }^{\mathrm{a}} \mathrm{P}<0.05$ vs. the $\mathrm{C}$ group; ${ }^{\mathrm{b}} \mathrm{P}<0.05$ vs. the $\mathrm{M}$ group. $\mathrm{SD}$, standard deviation.

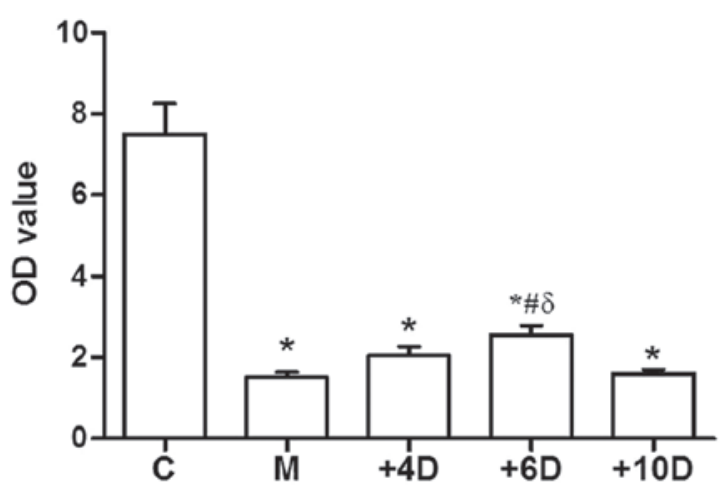

Figure 1. Effect of $1,25(\mathrm{OH})_{2} \mathrm{D}_{3}$ on proliferation index of spleen lymphocytes. ${ }^{~} \mathrm{P}<0.05$ vs. $\mathrm{C}$ group; ${ }^{~} \mathrm{P}<0.05$ vs. $\mathrm{M}$ group; ${ }^{\delta} \mathrm{P}<0.05$ vs. $+4 \mathrm{D}$ group. $1,25(\mathrm{OH})_{2} \mathrm{D}_{3}, 1,25$-dihydroxy-vitamin $\mathrm{D} 3$.

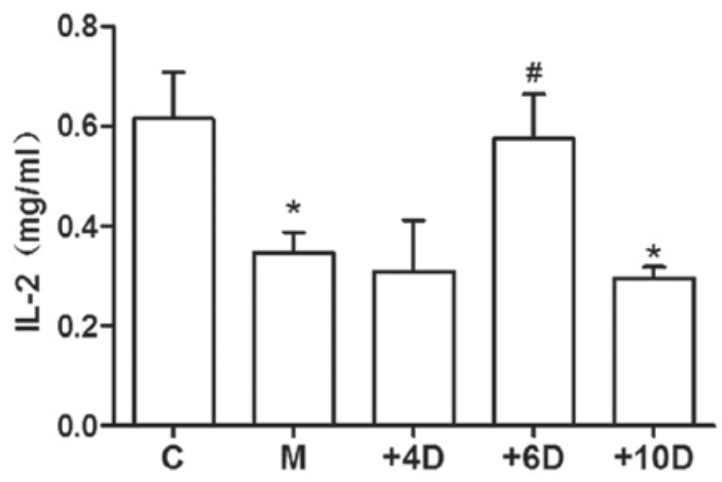

Figure 2. Effect of $1,25(\mathrm{OH})_{2} \mathrm{D}_{3}$ on IL-2 production in spleen lymphocytes. ${ }^{*} \mathrm{P}<0.05$ vs. $\mathrm{C}$ group; ${ }^{\#} \mathrm{P}<0.05$ vs. $\mathrm{M}$ group. $1,25(\mathrm{OH})_{2} \mathrm{D}_{3}, 1,25$-dihydroxy-vitamin D3; IL-2, interleukin-2.

C group. When mice were given $1,25(\mathrm{OH})_{2} \mathrm{D}_{3}$ for 7 days, the thymus indexes increased compared with the mice in the $\mathrm{M}$ group $(\mathrm{P}<0.05)$. Among the three vitamin $\mathrm{D}$-treated groups, the recovery of the thymus index in mice of the $+6 \mathrm{D}$ group was the most significant. However, for the spleen indexes, there was no difference between vitamin D-treated mice and the mice in M group (Table I).

$1,25(\mathrm{OH})_{2} \mathrm{D}_{3}$ promotes proliferation of lymphocytes in spleen. We evaluated the effects of $1,25(\mathrm{OH})_{2} \mathrm{D}_{3}$ on the proliferation of $\mathrm{T}$ lymphocytes in spleen. As shown in Fig. 1, the proliferation index of lymphocytes was obviously inhibited

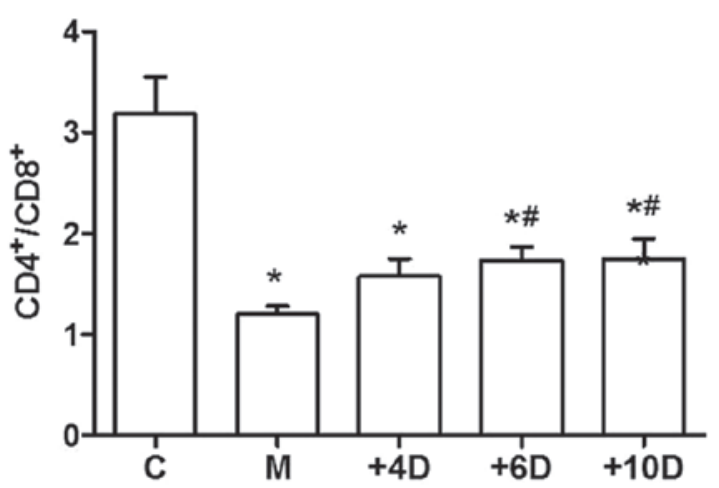

Figure 3. Effect of $1,25(\mathrm{OH})_{2} \mathrm{D}_{3}$ on the ratio of $\mathrm{CD}^{+}$to $\mathrm{CD}^{+} \mathrm{T}$ cells (mean $\pm \mathrm{SD}$ ). ${ }^{*} \mathrm{P}<0.05$ vs. $\mathrm{C}$ group; ${ }^{\#} \mathrm{P}<0.05$ vs. $\mathrm{M}$ group. $1,25(\mathrm{OH})_{2} \mathrm{D}_{3}$, 1,25-dihydroxy-vitamin D3. SD, standard deviation.

by the glucocorticoid hormone. The proliferation index was

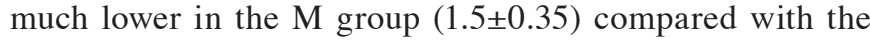
$\mathrm{C}$ group (7.49 $\pm 2.16, \mathrm{P}=0.01)$. However, the proliferation index was higher in the $+6 \mathrm{D}$ group $(2.55 \pm 0.66)$ compared to the $\mathrm{M}$ group $(1.50 \pm 0.35, \mathrm{P}=0.021)$. Differences of proliferation indexes of mice were not significant between $\mathrm{M}$ group and the other two $1,25(\mathrm{OH})_{2} \mathrm{D}_{3}$-treated groups.

$1,25(\mathrm{OH})_{2} \mathrm{D}_{3}$ promotes the production of IL-2 in spleen lymphocytes. To investigate the effects of $1,25(\mathrm{OH})_{2} \mathrm{D}_{3}$ on the function of T lymphocytes in spleen, the production of IL-2 in cultures of lymphocytes was detected. As expected, the secretion of IL-2 in spleen lymphocytes was significantly inhibited by glucocorticoid hormone injection in mice of the $\mathrm{M}$ group $(\mathrm{P}<0.01)$. However, mice supplemented with $1,25(\mathrm{OH})_{2} \mathrm{D}_{3}(6 \mathrm{IU} / \mathrm{g})$ had much higher levels of IL-2 $(0.58 \pm 0.22 \mathrm{mg} / \mathrm{l})$ compared to the $\mathrm{M}$ group $(0.35 \pm 0.10 \mathrm{mg} / 1, \mathrm{P}=0.03)$. The level of IL-2 in mice of the $+6 \mathrm{D}$ group was similar to that in the control group. However, IL-2 production of spleen lymphocytes in mice of the $+4 \mathrm{D}$ and $+10 \mathrm{D}$ groups was not different from that in mice of the M group (Fig. 2).

$1,25(\mathrm{OH})_{2} \mathrm{D}_{3}$ upregulates the ratio of $\mathrm{CD} 4^{+}$to $\mathrm{CD} 8^{+}$T lymphocytes. To investigate the effects of $1,25(\mathrm{OH})_{2} \mathrm{D}_{3}$ on the immune functions, we examined the ratio of $\mathrm{CD} 4^{+}$to $\mathrm{CD} 8^{+} \mathrm{T}$ cells in peripheral blood. As the data show in Fig. 3, the $\mathrm{CD}^{+} / \mathrm{CD}^{+}$ ratio in the $M$ group (1.20 \pm 0.24$)$ was significantly decreased compared to that in the $\mathrm{C}$ group $(3.18 \pm 1.04 ; \mathrm{P}<0.05)$. The ratios of $\mathrm{CD}^{+} / \mathrm{CD}^{+} \mathrm{T}$ cells were $1.58 \pm 0.49,1.74 \pm 0.35$ and 
$1.75 \pm 0.57$ in the $+4 \mathrm{D},+6 \mathrm{D}$ and $+10 \mathrm{D}$ groups, respectively. The ratio of $\mathrm{CD}^{+} / \mathrm{CD}^{+} \mathrm{T}$ cells was significantly higher in mice treated with $1,25(\mathrm{OH})_{2} \mathrm{D}_{3}$ at doses of 6 and $10 \mathrm{IU} / \mathrm{g}$ body weights compared with that in mice of the M group (Fig. 3).

\section{Discussion}

Previous reports regarding the effects of $1,25(\mathrm{OH})_{2} \mathrm{D}_{3}$ on the regulation of immune function were inconsistent. Most evidence of epidemiological studies, animal and in vitro experiments suggest a role for $1,25(\mathrm{OH})_{2} \mathrm{D}_{3}$ in negatively influencing the $\mathrm{T}$ cells in autoimmune disorders $(9,13)$. The results of an in vivo study suggest that $1,25(\mathrm{OH})_{2} \mathrm{D}_{3}$ supplementation inhibits the proliferation of $\mathrm{T}$ lymphocytes, reduces the immune organ indexes and decreases the ratio of $\mathrm{CD}^{+} / \mathrm{CD}^{+} \mathrm{T}$ cells in a model of adjuvant arthritis (14). In mice stimulated with Bacillus Calmette-Guerin, vitamin D deficiency may result in increasing the percentage of $\mathrm{CD}^{+}$ and $\mathrm{CD}^{+} \mathrm{T}$ cells and reducing the $\mathrm{CD} 4^{+} / \mathrm{CD}^{+}$ratio, while $1,25(\mathrm{OH})_{2} \mathrm{D}_{3}$ supplementation leads to a reduction of $\mathrm{CD} 4^{+}$and $\mathrm{CD}^{+} \mathrm{T}$ lymphocytes and elevation of $\mathrm{CD}^{+} / \mathrm{CD}^{+}$ratio. These results suggest that vitamin $\mathrm{D}$ exerts immunosuppressive effects in autoimmune diseases. By contrast, data from a clinical study show that the immunity of patients with long-term type 2 diabetes may be improved by vitamin $\mathrm{D}$ supplementation (11). Furthermore, the study of Gao et al suggests that the concentrations of $25(\mathrm{OH}) \mathrm{D}$ in patients with tuberculosis is lower than that in healthy adults, and $25(\mathrm{OH}) \mathrm{D}$ has a positive correlation with the $\mathrm{CD} 4^{+} / \mathrm{CD}^{+}$ ratio (15). A study by Panda et al, an animal model of 1- $\alpha$ hydroxylase deficiency was used to investigate the effects of $1,25(\mathrm{OH})_{2} \mathrm{D}_{3}$ on immune function. Their result showed that vitamin $\mathrm{D}$ deficiency resulted in the inhibition of the proliferation of spleen lymphocyte and a reduction in $\mathrm{CD}^{+}$ and $\mathrm{CD}^{+}$peripheral $\mathrm{T}$ cells (16). The results presented in our study showed that $1,25(\mathrm{OH})_{2} \mathrm{D}_{3}$ may improve the thymus index recovery, promote the IL-2 production and proliferation of $\mathrm{T}$ cells and elevate $\mathrm{CD} 4^{+} / \mathrm{CD} 8^{+}$ratio in glucocorticoid-induced immunosuppressant mice. The data indicates that $1,25(\mathrm{OH})_{2} \mathrm{D}_{3}$ has a positive influence on immune function under the state of hypoimmunity. The immunomodulatory effects of $1,25(\mathrm{OH})_{2} \mathrm{D}_{3}$ may be dependent on the immune status.

How vitamin D affects the immune system has not been fully elucidated. Previous studies have demonstrated that $\mathrm{T}$ cells express VDR (17). In addition, activated T cells express Cyp27B1 (vitamin D activating enzyme) $(18,19)$. Those studies suggest that $\mathrm{T}$ cells are not only the targets of $1,25(\mathrm{OH})_{2} \mathrm{D}_{3}$ but are also able to produce $1,25(\mathrm{OH})_{2} \mathrm{D}_{3}$ locally. IL-2, secreted by type 1 helper $\mathrm{T}$ cells, mediates the cellular immune response and can induce the proliferation of $\mathrm{T}, \mathrm{B}$ and natural killer cells (20). IL-2 may participate in the regulatory effects of vitamin D on immune system. A study showed that IL-2 secreted by $\mathrm{CD}^{+} \mathrm{T}$ cells was enhanced by $1,25(\mathrm{OH})_{2} \mathrm{D}_{3}$ treatment (21). Additionally, in vitro treatment with $1,25(\mathrm{OH})_{2} \mathrm{D}_{3}$ may upregulate the expression of IL-2 receptor in T lymphocytes and monocytes (22). The current study showed that vitamin $\mathrm{D}$ enhanced IL-2 production of $\mathrm{T}$ cells in spleen. Thus, the changes of IL-2 production may participate in the immune regulatory effects of vitamin D.
$\mathrm{T}$ cells mainly include $\mathrm{CD} 4^{+} \mathrm{T}$ cells and $\mathrm{CD} 8^{+} \mathrm{T}$ cells The $\mathrm{CD}^{+} / \mathrm{CD}^{+}$ratio has been recognized as an important indicator for evaluating the state of immunomodulation and response to homeostasis of the intrinsic immune system (23). Previous studies have shown that the increased $\mathrm{CD} 4^{+} / \mathrm{CD}^{+}$ ratio has been observed in many autoimmune diseases such as SLE (24), inflammatory bowel disease (25) and multiple sclerosis (26). A low $\mathrm{CD}^{+} / \mathrm{CD}^{+}$ratio was considered as a marker of decreased immune function (27), which could result in increasing the risk of HIV-infected, pulmonary tuberculosis and even some tumors $(28,29)$. The current study demonstrated that the CD4/CD8 ratio significantly decreased by glucocorticoid injection and partially recovered by vitamin D supplementation. These results further prove that vitamin D may improve the immune status in immunosuppressant conditions.

The present findings have demonstrated that vitamin D can partially improve the immune recovery in immunosuppressant mice by stimulating $\mathrm{T}$-cell proliferation and elevating IL-2 production.

\section{Acknowledgements}

The present study was supported by The Medical Research Grant of The 306th Hospital of PLA, Beijing, China.

\section{References}

1. Wang Y, Zhu J and DeLuca HF: Where is the vitamin D receptor? Arch Biochem Biophy 523: 123-133, 2012.

2. Overbergh L, Decallonne B, Valckx D, Verstuyf A, Depovere J, Laureys J, Rutgeerts O, Saint-Arnaud R, Bouillon R and Mathieu C: Identification and immune regulation of 25-hydroxyvitamin D-1-alpha-hydroxylase in murine macrophages. Clin Exp Immunol 120: 139-146, 2000.

3. Hewison M, Freeman L, Hughes SV, Evans KN, Bland R, Eliopoulos AG, Kilby MD, Moss PA and Chakraverty R: Differential regulation of vitamin $\mathrm{D}$ receptor and its ligand in human monocyte-derived dendritic cells. J Immunol 170: 5382-5390, 2003

4. Prietl B, Treiber G, Pieber TR and Amrein K: Vitamin D and immune function. Nutrients 5: 2502-2521, 2013.

5. Soilu-Hänninen M, Airas L, Mononen I, Heikkilä A, Viljanen M and Hänninen A: 25-Hydroxyvitamin D levels in serum at the onset of multiple sclerosis. Mult Scler 11: 266-271, 2005.

6. Correale J, Ysrraelit MC and Gaitán MI: Immunomodulatory effects of vitamin D in multiple sclerosis. Brain 132: 1146-1160, 2009.

7. Staples JA, Ponsonby AL, Lim LL and McMichael AJ: Ecologic analysis of some immune-related disorders, including type 1 diabetes, in Australia: Latitude, regional ultraviolet radiation, and disease prevalence. Environ Health Perspect 111: 518-523, 2003.

8. Ruiz-Irastorza G, Egurbide MV, Olivares N, Martinez-Berriotxoa A and Aguirre C: Vitamin D deficiency in systemic lupus erythematosus: Prevalence, predictors and clinical consequences. Rheumatology (Oxford) 47: 920-923, 2008.

9. Ye YL, Li ZX and Ye XM: Influence of 1,25-dihydroxyvitamin D3 on variation of peripheral blood lymphocyte subsets in guinea pigs with experimental autoimmune encephalomyelitis. J Chin Gen Pract 11: 391-393, 2008 (In Chinese).

10. Wu J, Zhang J, Hou GH, Cui YB, Wang C and Chen J: Effect of 1 $\alpha, 25$-dihydroxyvitamin D3 on Thelper cell 17 and expression of related cytokines in penetrating keratoplasty in mice. Chin J Pathophysiol 30: 2226-2231, 2014 (In Chinese).

11. Luwen C, Liqing T and Ruiping Y: Study of impact of vitamin D in immune function and infections in patients with type 2 diabetes. Chin J Nosocomiol 25: 1106-1109, 2015.

12. Dezhi L, Zehua Z, Litao L and Zhengqi C: Effection of vitamin D deficiency to $\mathrm{T}$ lymphocyte subgroups in spinal tuberculosis Chin. J Orthop 20: 448-450, 2012. 
13. Cantorna MT, Snyder L, Lin YD and Yang L: Vitamin D and 1,25(OH)2D regulation of T cells. Nutrients 7: 3011-3021, 2015.

14. Wang C, Wu J, Hou GH, Chen J, Qi WJ, Cui YB and Zhang J: The immuno-regulation effect of $1,25(\mathrm{OH})_{2} \mathrm{D}_{3}$ on T lymphocytes. J Guangdong Med 34: 3114-3116, 2013.

15. Gao WW, Wang Y, Zhang XR, Yin CY, Hu CM, Tian M, Wang HW and Zhang X: Levels of $1,25(\mathrm{OH})_{2} \mathrm{D}_{3}$ for patients with pulmonary tuberculosis and correlations of $1,25(\mathrm{OH})_{2} \mathrm{D}_{3}$ with the clinical features of TB. J Thorac Dis 6: 760-764, 2014

16. Panda DK, Miao D, Tremblay ML, Sirois J, Farookhi R, Hendy GN and Goltzman D: Targeted ablation of the 25-hydroxyvitamin D 1alpha -hydroxylase enzyme: Evidence for skeletal, reproductive, and immune dysfunction. Proc Natl Acad Sci USA 98: 7498-7503, 2001.

17. Schedel M, Jia Y, Michel S, Takeda K, Domenico J, Joetham A, Ning F, Strand M, Han J, Wang M, et al: 1,25D3 prevents CD8(+) Tc2 skewing and asthma development through VDR binding changes to the Cyp1la1 promoter. Nat Commun 7: 10213, 2016.

18. Ooi JH, McDaniel KL, Weaver V and Cantorna MT: Murine CD8 + T cells but not macrophages express the vitamin D $1 \alpha$-hydroxylase. J Nutr Biochem 25: 58-65, 2014.

19. Kongsbak M, von Essen MR, Levring TB, Schjerling $P$, Woetmann A, Ødum N, Bonefeld CM and Geisler C: Vitamin D-binding protein controls $\mathrm{T}$ cell responses to vitamin D. BMC Immunol 15: 35, 2014

20. Lu Z, Jin M, Huang M, Wang Y and Wang Y: Bioactivity of selenium-enriched exopolysaccharides produced by Enterobacter cloacae Z0206 in broilers. Carbohydr Polym 96: 131-136, 2013.

21. Yan G, Xi Y, Xu S, Chen J, Lin Y, Dai H, Cheng P, Xiao H, Liu Z and Qi Z: Inhibiting accelerated rejection mediated by alloreactive CD4(+) memory $\mathrm{T}$ cells and prolonging allograft survival by $1 \alpha, 25$-dihydroxyvitamin $\mathrm{D}(3)$ in nude mice. Immunol Lett 149: 54-61, 2013.

22. Prehn JL and Jordan SC: Incubation of T cell or monocytic cell lines with 1,25-dihydroxyvitamin D3 before mitogen stimulation potentiates IL-2 and IL-1 beta mRNA levels. Transplant Proc 21: 90-91, 1989.
23. Dhur A, Galan P, Preziosi P and Hercberg S: Lymphocyte subpopulations in the thymus, lymph nodes and spleen of iron-deficient and rehabilitated mice. J Nutr 121: 1418-1424, 1991.

24. Zhao L, Jiang Z, Jiang Y, Ma N, Wang K and Zhang Y: Changes in immune cell frequencies after cyclophosphamide or mycophenolate mofetil treatments in patients with systemic lupus erythematosus. Clin Rheumatol 31: 951-959, 2012.

25. Wang FY, Su M, Zheng YQ, Wang XG, Kang N, Chen T, Zhu EL, Bian ZX and Tang XD: Herbal prescription Chang'an II repairs intestinal mucosal barrier in rats with post-inflammation irritable bowel syndrome. Acta Pharmacol Sin 36: 708-715, 2015.

26. Harrer A, Pilz G, Wipfler P, Oppermann K, Sellner J, Hitzl W, Haschke-Becher E, Afazel S, Rispens T, van der Kleij D, et al: High interindividual variability in the CD4/CD8 T cell ratio and natalizumab concentration levels in the cerebrospinal fluid of patients with multiple sclerosis. Clin Exp Immunol 180: 383-392, 2015.

27. Hadrup SR, Strindhall J, Køllgaard T, Seremet T, Johansson B, Pawelec G, thor Straten P and Wikby A: Longitudinal studies of clonally expanded CD8 T cells reveal a repertoire shrinkage predicting mortality and an increased number of dysfunctional cytomegalovirus-specific $\mathrm{T}$ cells in the very elderly. J Immunol 176: 2645-2653, 2006.

28. Yin Y, Qin J, Dai Y, Zeng F, Pei $\mathrm{H}$ and Wang J: The $\mathrm{CD} 4^{+} / \mathrm{CD}^{+}$ ratio in pulmonary tuberculosis: Systematic and meta-analysis article. Iran J Public Health 44: 185-193, 2015.

29. Serrano-Villar S, Sainz T, Lee SA, Hunt PW, Sinclair E, Shacklett BL, Ferre AL, Hayes TL, Somsouk M, Hsue PY, et al: HIV-infected individuals with low CD4/CD8 ratio despite effective antiretroviral therapy exhibit altered $\mathrm{T}$ cell subsets, heightened CD8+ $\mathrm{T}$ cell activation, and increased risk of non-AIDS morbidity and mortality. PLoS Pathog 10: e1004078, 2014. 